\title{
INCREASING INTERCULTURAL COMPETENCE AND TOLERANCE IN MULTICULTURAL SCHOOLS: A TRAINING PROGRAM AND ITS EFFECTIVENESS
}

\author{
Nadezhda M. Lebedeva \\ National Research University, Moscow, Russia \\ E-mail: nlebedeva@hse.ru \\ Elena Makarova, \\ University of Bern, Bern, Switzerland \\ E-mail: elena.makarova@edu.unibe.ch \\ Alexander Tatarko \\ National Research University, Moscow, Russia \\ E-mail: atatarko@hse.ru
}

\begin{abstract}
This study reports the implementation of a Training of Intercultural Competence and Tolerance (TICT) for upper-secondary school students and the empirical evaluation of its effectiveness. The TICT program was developed to counteract increasing interethnic conflicts in the North Caucasus Federal District of Russia. It is based on the theoretical and empirical framework of social psychology and cross-cultural psychology. The training effectiveness was assessed by conducting pre-and post-surveys among the training participants. The results indicate that TICT contributes to the development of a positive ethnic identity and the formation of a civic identity among the participating youth. It also increases their optimism regarding the future of interethnic relations in Russia and the subjective level of intercultural competence of majority group youth towards minority cultures. Thus, the evaluation of the training effectiveness of the TICT has shown that the aims of the training have been achieved to a large extent and that the Training of Intercultural Competence and Tolerance can be effectively used to prevent interethnic conflicts and promote interethnic relations in multicultural schools. Suggestions for the practical implementation of the TICT as well as for future research on the training's effectiveness are discussed.

Key words: intercultural competence, tolerance, training, students.
\end{abstract}

\section{Introduction}

The Training of Intercultural Competence and Tolerance (TICT) was developed on the basis of field research conducted between 2001 and 2004 in multicultural regions of the Russian Federation (Lebedeva, \& Tatarko, 2003, 2004) in order to counteract increasing interethnic conflicts in the North Caucasus.

The North Caucasus Federal District in the southwest of the European part of Russia includes one federal subject (the Stavropol Krai) and six republics (i.e. Dagestan, Ingushetia, North Ossetia, Kabardino-Balkar, Karachay-Cherkess, and Chechnya), making it the most multicultural region of the Russian Federation with more than 130 ethnic groups. The ethnic heterogeneity of the North Caucasus has been increasing due to intensive migration from the states of the South Caucasus, i.e. from Armenia, Georgia and Azerbaijan (Federal State Statis- 
Nadezhda M. LEBEDEVA, Elena MAKAROVA, Alexander TATARKO. Increasing Intercultural Competence and Tolerance in Multicultural Schools: A Training Program and Its Effectiveness

\begin{abstract}
PROBLEMS
OF EDUCATION

IN THE $21^{\text {st }}$ CENTURY

Volume 54,2013

40 tics Service, 2011). For many years, the North Caucasus Federal District has been politically unstable and has often witnessed ethnic and religious tensions.

Consequently, the program presented here aimed to reduce ethnic and religious prejudices and increase mutual understanding among adolescents through the training of intercultural competence and tolerance. More specifically, its goals were to reduce anxiety in intercultural interactions, overcome ethnic prejudices and negative stereotypes, form cognitive and emotional empathy, develop an isomorphic attribution of outgroup behavior, form a common identity, and model positive behavior patterns in intercultural interaction. The program was subsequently tested in five multicultural regions of Russia (the Chuvash Republic, Stavropol Krai, the Southern and North Caucasus Federal Districts, Moscow and the Kaluga regions) as well as in other countries such as Lithuania, the Ukraine, and Armenia. The training was evaluated using a preand post-program survey of upper-secondary school students from the Stavropol Krai.
\end{abstract}

\title{
Theoretical and Empirical Background of the TICT Program
}

The training program's broad theoretical and empirical background is based on concepts from social psychology and cross-cultural psychology.

In the social psychological tradition, the following approaches have been used by a number of field and laboratory studies to investigate intercultural relations: Social Identity Theory (e.g. Tajfel, \& Turner, 1986), Self-Categorisation Theory (e.g. Turner, 1985), the concept of 'salience' of group identity' (Brown, 2000; Taylor, 2002), Realistic Group Conflict Theory (e.g. Sherif, 1966), the Instrumental Model of Group Conflict (e.g. Esses, Jackson, \& Armstrong, 1998), the Contact Hypothesis (Allport, 1954), Intergroup Contact Theory (e.g. Pettigrew, \& Tropp 2006), integrated Threat Theory of Prejudice (Stephan \& Stephan, 2000, 2001), and the Common Ingroup Identity Model (e.g. Gaertner, \& Dovidio, 2000). Studies originating from the theoretical and empirical framework of social psychology focus on topics such as ethnocentrism, ethnic prejudice, ethnic stereotypes, ethnic attitudes and their change, and discrimination (e.g. Hagendoorn, 1993; Kalin, \& Berry 1996; Stephan, \& Stephan 1996; Voci, \& Hewstone, 2003).

In the tradition of cross-cultural psychology, acculturation research has been one of the main topics of interest (Berry, 2003; Ward, 2001). Contemporary research on acculturation analyzes acculturation attitudes and behaviors along two dimensions: maintenance of the heritage culture and adoption of the host society culture (Berry, 2005, p. 705; Berry, 2006a, p. 35). With respect to acculturation preferences of non-dominant groups, empirical evidence shows that integration (i.e. a high degree of maintenance of the culture of the ethnic origin as well as high degree of adoption of the culture of the host society) is usually the most successful strategy (Berry, \& Sabatier, 2010; Pfafferott, \& Brown, 2006). Regarding the mutual perception of acculturation preferences in multicultural societies, Roccas, Horenczyk, and Schwartz (2000) showed that immigrants' perception of their own acculturation preferences were not shared by representatives of the host society. The most significant discrepancies in perception were observed when "the immigrants believed that members of the dominant society expected them to relinquish their unique identity and to assimilate much more than they themselves were ready to do" (ibid., p. 331). Pfafferott and Brown (2006) hypothesize that such discrepancies between own acculturation attitudes and perceived attitudes of the other group may influence intergroup relations. Furthermore, this gap between majority and minority groups with regard to perception of acculturation attitudes has been shown to have problematic or even conflicting consequences (Montreuil, \& Bourhis, 2004; Navas, García, Sánchez, Rojas, Pumares, \& Fernández, 2005).

Regarding the acculturation process among children and youth, Berry, Poortinga, Breugelmans, Chasiotis, and Sam (2011) highlight the school context as one of the more important settings of ongoing and continual acculturation. "Schools and other educational settings constitute the main acculturation context for immigrant children and youth. They can be viewed 
as a miniature society of settlement; schools represent and introduce the culture to immigrant children. School adjustment can be seen as a primary task, and as a highly important outcome,

PROBLEMS OF EDUCATION IN THE $211^{\text {st }}$ CENTURY Volume 54, 2013 of the cultural transition process" (ibid., p. 326). Research on acculturation in the school context has shown that the acculturation strategies favored by students and their teachers influence the quality of the student-student and teacher-student relationships. In short, those immigrant youth who wish simultaneously to maintain their ethnic cultural heritage as well as to adopt the mainstream culture have the best prospects of being socially integrated at school. Furthermore, immigrant youth's social integration in the school context is supported by teachers favoring an integration strategy (Makarova, \& Herzog, 2011).

With respect to the development of the training program, two approaches to acculturation - the social identification perspective and the social learning approach - were particularly central. The social identification perspective on acculturation is based on the social psychological conceptualization of identity and focuses on an individual's self-identification with an ethnocultural group. It is related to individual or group-specific acculturation (Phinney, 2003). The social identification perspective hence claims that individuals can retain their ethnic label or choose the label of a host country, or even combine these two (Phinney, Horenczyk, Liebkind, \& Vedder, 2001). The social learning approach, on the other hand, assumes that the nature of personal or group interaction varies according to culture types (Hofstede, 1980; Markus, \& Kitayama, 1991) and analyzes aspects of behavior under the conditions of intercultural contact between different cultural patterns and value systems. Hence, culture contact appears as a major and a stressful life event that leads to "culture shock" (Ward, Bochner, \& Furnham, 2001) or "acculturative stress" (Berry, 2006b). Therefore, it is expected that the acquisition of new skills is essential to successfully manage interaction and communication in a new cultural context (Bennett, 1986; Landis, Bennett, \& Bennett, 2004).

The empirical evidence from these theoretical approaches and empirical studies was used for the development of our Training program of Interculturual Communication and Tolerance (TICT) for multicultural schools..

\section{TICT Program Description}

According to Stephan and Stephan (2001), the psychological processes which lead to increasing intercultural competence and tolerance take place along two corresponding dimensions: (i) active versus passive processes and (ii) affective versus cognitive processes. These two dimensions were adapted in the TICT to classify the psychological processes addressed by the training (see Table 1).

\section{Table 1. Psychological processes addressed in the TICT.}

\begin{tabular}{lll}
\hline & Cognitive & Affective \\
\hline Active & $\begin{array}{l}\text { Modeling positive intergroup behavior; } \\
\text { Altering incorrect attributions; } \\
\text { Emphasizing multiple identities. }\end{array}$ & $\begin{array}{l}\text { Enhancing positive intergroup behavior; } \\
\text { Detecting mismatch between values and } \\
\text { behavior. }\end{array}$ \\
& $\begin{array}{l}\text { Changing attitudes and subjective } \\
\text { norms; }\end{array}$ & $\begin{array}{l}\text { Reducing threat; } \\
\text { Forming emotional empathy. }\end{array}$ \\
& $\begin{array}{l}\text { Forming cognitive empathy; } \\
\text { Forming common groups; } \\
\text { Strengthening perceptions of similarities. }\end{array}$ & \\
\hline
\end{tabular}


Nadezhda M. LEBEDEVA, Elena MAKAROVA, Alexander TATARKO. Increasing Intercultural Competence and Tolerance in Multicultural Schools: A Training Program and Its Effectiveness

EMS

OF EDUCATION

IN THE $21^{\text {st }}$ CENTURY

Volume 54, 2013

From a methodological point of view, the program employs both known (Bargal, \& Bar, 1992; Bhawuk, \& Brislin, 2000; Brislin, \& Bhawuk, 1999; Brislin, Cushner, Cherrie, \& Yong, 1986; Brislin, \& Horvath, 1997; Brislin, \& Yoshida, 1994, Rot, \& Kopteltseva, 2001) and new, specially designed training methods of intercultural sensitization and competence.

The main goal of the training is to overcome ethnic prejudice. According to Berry, Poortinga, Segall, and Dasen (2008, p. 371), ethnic prejudice is assumed to be "a universal feature of intercultural relations" consistsing of three components, i.e. "cognitive (stereotypes; shared beliefs about characteristics of groups); affective (attitudes; evaluation of groups); and behavioral (discrimination; action taken in dealing with groups)". It is important to note, however, that stereotypes can be useful when dealing with cultural diversity in everyday life, but they can endanger intercultural relations if they are based on overgeneralization and negative attributes used to describe members of an ethnic outgroup. Therefore, the training aims to uncover and overcome negative stereotypes towards members of ethnic groups who are involved in interethnic interactions. Moreover, the training also aims at developing an ability to interpret the behavior of members of other cultures correctly and to act constructively in a situation of intercultural dialog. Finally, the training aims to form ethnic tolerance and a positive civic identity common to all people living in Russia.

The training program consists of six thematic sessions with particular aims for each session (see Table 2).

Table 2. Aims of the six thematic TICT sessions.

\begin{tabular}{|c|c|}
\hline Session & Aims \\
\hline 1 & $\begin{array}{l}\text { Familiarizing participants with each other, creating a favorable psychological climate, building } \\
\text { motivation (group and individual), elaborating group conventions and code of conduct, and forming } \\
\text { sensitivity to cultural peculiarities. }\end{array}$ \\
\hline 2 & $\begin{array}{l}\text { Raising the awareness of the cultural specificity of 'world views' and their reflection in folklore as } \\
\text { well as verbal and nonverbal behavior. }\end{array}$ \\
\hline 3 & $\begin{array}{l}\text { Developing skills to understand intercultural interactions when ethnic stereotypes and prejudice are } \\
\text { activated. }\end{array}$ \\
\hline 4 & $\begin{array}{l}\text { Increasing ethnocultural competence and sensitivity: The development of the ability to understand } \\
\text { life situations from the perspective of representatives of other ethnic groups; seeing the world from } \\
\text { the perspective of another culture. }\end{array}$ \\
\hline 5 & $\begin{array}{l}\text { Forming ideas about potential conflicts and possible behavioral models among students and devel- } \\
\text { oping their conflict management skills. }\end{array}$ \\
\hline 6 & $\begin{array}{l}\text { Developing skills for constructive intercultural dialog and forming a common ethnic identity (civic, } \\
\text { regional, and local). }\end{array}$ \\
\hline
\end{tabular}

Each training session provides exercises for students as well as instruction and manuals for trainers. The TICT program consists of more than 20 practical exercises to build skills for intercultural interaction among adolescents. The exercises are structured along the following six thematic sections (Lebedeva, Luneva, \& Stefanenko, 2004):

(1) Introduction to intercultural communication and ethnic tolerance training,

(2) Ethnic world views and intercultural communication,

(3) Ethnic stereotypes and prejudice, 
(4) Cultural assimilator,

(5) Conflicts in our lives, and

(6) Intercultural dialogue in games.

The exercises of the program have to be conducted and supervised by competent trainers who have the necessary knowledge about the theoretical and methodological background of the training, are familiar with the manual and materials and have detailed information about the social setting of the training. In order to characterize the social setting of the training in the school context, it is crucial to consider some main determinants of the setting:

1) The age of the participants in the training group

2) The characteristics of the group:

- temporary or permanent (e.g., class or club) group

- number of participants

- gender composition

- ethnocultural composition

- $\quad$ social status of group members

3) The status of the trainer:

- invited trainer

- class teacher

- school psychologist.

In what follows, two exercises of session 3 will be briefly described to provide an idea of the exercises' content and procedure.

\section{Sample Exercise 1: "Guess who they are talking about"}

Aim: Recognizing the existence of ethnic stereotypes and understanding their roles and functions in communication.

Procedure: Participants are given handouts with a set of stereotypical characteristics of certain ethnic groups and are asked to identify the groups. In the TICT- modified version of this exercise, there are two sets of characteristics: one containing only positive characteristics, and the other containing only negative characteristics of an ethnic groups. The results students come up with are subsequently discussed in the plenum.

Objectives: Raising the issue of ethnic stereotypes and their roles in inter-group interaction, in particular their function of protecting positive ethnic identity.

Note: When positive stereotypes are attributed predominantly to one's own group, and negative stereotypes to an ethno-contact group, the existence of intergroup tension, hidden (or even open) conflict, mutual resentment, or feelings of intergroup threat can be assumed. If participants find it difficult to attribute these projections to any real ethnic group, the discussion should reveal the projective nature of these stereotypes and show that the given task can serve as a good diagnosis of the degree of tension and conflict of intercultural communication in real life.

Sample Exercise 2: "A Web of Prejudices"

Aim: Gain and constructively work out experience in situations where ethnic stereotypes and prejudice are manifest.

Procedure: The discussion consists of two stages.

First stage: Verbalization of feelings, exchanging feelings and emotions: This stage of the discussion should focus on expressing and exchanging feelings. The trainer should ensure 
Nadezhda M. LEBEDEVA, Elena MAKAROVA, Alexander TATARKO. Increasing Intercultural Competence and Tolerance in Multicultural Schools: A Training Program and Its Effectiveness

EMS

OF EDUCATION

IN THE $21^{\text {st }}$ CENTURY

Volume 54, 2013

that all the members of the group reflect on their feelings. After this, the trainer may invite the group members to address other participants with words, or to perform an action. The trainer and the group must subsequently thank the main characters of the role-play, express admiration for them, etc.

Second stage: Elaborating strategies for coping with negative ethnic stereotypes: At this stage, it is important to direct the group discussion towards the formation of individual strategies of coping with negative ethnic stereotypes and prejudices. For this, the trainer should ask those who performed the role-play on the 'chair' and, afterwards, all the participants the following question: "What helped you personally, and what in general can help the person overcome the negative impact of stereotypes?".

Objectives:

- Displaying to the group members the feelings of a person who is the object of negative ethnic stereotypes and prejudice;

- Helping the group members to recognize the influence of stereotypes on the feelings and functional status of people who are the object of stereotyping;

- Fostering motivation among group members to assist and support the person who is feeling humiliated by stereotypes and prejudices;

- Elaborating, during the group discussion, strategies of coping with negative ethnic stereotypes (formation of positive behaviors in intergroup interaction).

Note: Possible strategies of coping with negative ethnic stereotypes for those who are subjected to stereotyping and for those who use negative ethnic stereotypes should be recognized and pointed out by the trainer.

\section{Program Evaluation}

\section{General Background}

Following Stephan and Stephan (2001), the Training of Intercultural Competence and Tolerance was evaluated by combining qualitative and quantitative methods.

The qualitative evaluation of the TICT was based on the unsystematic observations of the program by trainers who conducted the TICT. This approach helps to identify the strengths and weaknesses of the training program from the trainers' point of view. However, it should be noticed that observers have their own expectations of the program and the results of their analysis are not immune to the "effect of prejudice" (Lebedeva, Luneva, \& Stefanenko, 2004).

A quantitative approach is more efficient since it provides more accurate information regarding the psychological processes that underline changes produced through the training program. Therefore, only this part of the TICT evaluation was chosen to assess the effectiveness of the program. The quantitative evaluation of the TICT was performed using pre- and postsurveys among the training participants.

\section{Sample}

Overall, 103 (46 male and 57 female) 10th and 11th grade upper-secondary students aged 16-17 years from the Stavropol Krai (the Southern Federal district of the Russian Federation) were surveyed in October 2003. The majority group sample consisted of 64 Russian students and the minority group sample of 39 students originating from different ethno-cultural groups of the North Caucasus region. To represent the high diversity of the ethnic population of the region, the minority group sample included representatives from the following ethnic groups: Armenians (12 students), Dagestani (10 students), Chechens (6 students), Azerbaijanis (3 students), Karachai (3 students), Georgians (2 students), Kabardian (2 students), and Circassians (1 student). 


\section{Instrument and Procedures}

The TICT was evaluated using a pre- and post-design to measure training effectiveness. The pre- and post-surveys were conducted by the trainers using a standardized questionnaire. All students who participated in the TICT were surveyed. The pre-survey was conducted before the beginning of the training on the first day. The training lasted five days. The post-survey was conducted after the training on the fifth day.

The following six measurement units were applied as dependent variables in the pre- and post-survey in order to measure the effectiveness of the training. The first unit consisted of four 4-item scales measuring such constructs as: (i) valence of ethnic identity (Berry, \& Pleasants, 1984; Berry, \& Kalin, 1995), (ii) ambivalence of ethnic identity (Brown, 2000; Author, 2004), (iii) intensity of common identity (Stephan, \& Stephan, 2001), and (iv) optimism towards the future of interethnic relations (Stephan, \& Stephan, 2001). The scales of this unit ranged from minimally 4 to maximally 28 points. The negative pole of the scale was defined as 4 to 12 points, uncertainty was defined as the range between 13 and 15 points, and the positive pole was defined as the range between 16 and 28 points.

The other five units were measured using the following scales (Stephan, \& Stephan, 2001): intergroup anxiety scale, intergroup empathy scale, intergroup attitude scale, intergroup interaction scale, and subjective evaluation of own competences towards the culture of an outgroup. The scales of these units ranged from a minimum of 1 to a maximum of 7 points.

\section{Data Analysis}

The students' ratings in the pre- and post-surveys were analyzed using the following non-parametric statistics: Wilcoxon test $(\mathrm{T})$, sign-test $(\mathrm{G})$, and Kendall's tau $(\tau)$ coefficient. The data were first analyzed across the total sample and then separately within the majority and the minority group samples.

\section{Results of the Program Evaluation}

Participation in the TICT noticeably increased the valence of ethnic identity $\left(\mathrm{M}_{\mathrm{pre}}=20.2\right.$; $\left.\mathrm{M}_{\text {post }}=24.1\right)$ and slightly strengthened the intensity of a common Russian identity $\left(\mathrm{M}_{\mathrm{pre}}^{\mathrm{pre}}=17.5\right.$; $\mathrm{M}_{\text {post }}^{\text {post }}=18.4$ ) in participants. The most remarkable change, however, was in the level of participants' optimism towards future interethnic relations in the multiethnic society of the Russian Federation: While the participants expressed uncertainty towards future interethnic relations before the training $\left(\mathrm{M}_{\mathrm{pre}}=15.4\right)$, they had clearly positive attitudes after the training $\left(\mathrm{M}_{\text {post }}=\right.$ 18.7) towards future intergroup relations (see Table 3).

Table 3. Changes from pre- to post-survey (total sample).

\begin{tabular}{llllll}
\hline & $\begin{array}{l}\text { Pre } \\
\text { (M) }\end{array}$ & $\begin{array}{l}\text { Post } \\
\text { (M) }\end{array}$ & $\begin{array}{l}\text { Pre-Post } \\
\text { bias }\end{array}$ & $\begin{array}{l}\text { T-test } \\
\mathbf{p}\end{array}$ & $\begin{array}{l}\text { G-test } \\
\mathbf{p}\end{array}$ \\
\hline Valence of ethnic identity & 20.2 & 24.1 & $(+)$ & 0.05 & n.s. \\
Optimism towards interethnic relations & 15.4 & 18.7 & $(+)$ & 0.004 & 0.02 \\
Intensity of common identity & 17.5 & 18.4 & $(+)$ & n.s. & 0.03 \\
\hline Note: positive pre- and post-survey bias (+), negative pre- and post-survey bias (-); n.s.= non-significant.
\end{tabular}

As shown in Table 4 below, the intensity of a common civic identity and the valence of ethnic identity correlated significantly positively in the pre- and post-survey, suggesting that these constructs change simultaneously. 
Nadezhda M. LEBEDEVA, Elena MAKAROVA, Alexander TATARKO. Increasing Intercultural Competence and Tolerance in Multicultural Schools: A Training Program and Its Effectiveness

PROBLEMS

OF EDUCATION

IN THE $21^{\text {st }}$ CENTURY

Volume 54, 2013

A positive correlation between the intensity of the participants' common civic identity and their optimism towards interethnic relations in the both surveys supports the idea that the development of a common civic identity is important for intercultural relations between members of different ethnocultural groups within a multiethnic society (see Table 4).

Table 4. Correlation of the constructs in pre- and post-survey (total sample).

\begin{tabular}{lll}
\hline & Pre & Post \\
\hline Intensity of common identity/ Valence of ethnic identity & $\mathbf{T}$ & $\mathbf{T}$ \\
\hline Intensity of common identity/ Optimism towards interethnic relations & $0.19^{* *}$ & $0.14^{*}$ \\
\hline Note ${ }^{*} p<0.05 * *$ p $<0.01, * * * p<0.001$ & $0.26^{* *}$ & $0.27^{* *}$ \\
\hline
\end{tabular}

Note: ${ }^{*} \mathrm{p}<0.05,{ }^{* *} \mathrm{p}<0.01,{ }^{* * *} \mathrm{p}<0.001$.

\section{Training Effectiveness among Majority Group Members}

With respect to the training's effectiveness for participants belonging to the Russian majority group, the findings indicated that their anxiety vis-à-vis members of ethnocultural groups from the Caucasus region decreased significantly and reached the negative pole $\left(\mathrm{M}_{\text {pre }}=\right.$ 13.2; $\mathrm{M}_{\text {post }}=11.3$ ). In particular, the Russian participants' competence towards the cultures of the North Caucasus region (Chechnya, Ossetia, Dagestan and Armenia) increased significantly. However, competences of majority group members towards cultures of minority groups did not reach the positive pole on the scale between a minimum of 1 and a maximum of 7 points, even after the training $(\mathrm{M}=2.2 ; \mathrm{M}=1.7 ; \mathrm{M}=2.4 ; \mathrm{M}=2.9)$. This may be explained by the contents of the training which was not primarily geared toward providing such competences. At the same time, the fact of a more positive evaluation of own competences towards cultures of the North Caucasus among majority group members was a positive effect of the training (see Table 5).

Table 5. Changes from pre- to post-survey (majority group sample).

\begin{tabular}{llllll}
\hline & $\begin{array}{l}\text { Pre } \\
(\mathbf{M})\end{array}$ & $\begin{array}{l}\text { Post } \\
(\mathbf{M})\end{array}$ & $\begin{array}{l}\text { Pre-Post } \\
\text { bias }\end{array}$ & $\begin{array}{l}\text { T-test } \\
\mathbf{p}\end{array}$ & $\begin{array}{l}\text { G-test } \\
\mathbf{p}\end{array}$ \\
\hline Intergroup anxiety & 13.2 & 11.3 & $(-)$ & 0.05 & n.s. \\
Competences towards the culture of Chechnya & 1.4 & 2.2 & $(+)$ & 0.005 & 0.001 \\
Competences towards the culture of Ossetia & 1.2 & 1.7 & $(+)$ & 0.001 & 0.001 \\
Competences towards the culture of Dagestan & 1.5 & 2.4 & $(+)$ & 0.001 & 0.001 \\
Competences towards the culture of Armenia & 2.3 & 2.9 & $(+)$ & 0.001 & 0.001 \\
\hline
\end{tabular}

The results presented in Table 6 demonstrate that the participants from the majority group developed more competence towards two ethnocultural groups of the North Caucasus and decreased their anxiety vis-à-vis other ethnocultural groups after the training.

Table 6. Correlation of the constructs in pre- and post-survey (majority group sample).

\begin{tabular}{|c|c|c|}
\hline & Pre & Post \\
\hline & $T$ & $T$ \\
\hline Competences towards the culture of Dagestan/Intergroup anxiety & n.s. & $-0.31^{* *}$ \\
\hline Competences towards the culture of Chechnya/ Intergroup anxiety & n.s. & $-0.27^{*}$ \\
\hline
\end{tabular}

Note: ${ }^{*} \mathrm{p}<0.05, * * \mathrm{p}<0.01, * * * \mathrm{p}<0.001 ;$ n.s. $=$ non-significant. 
Nadezhda M. LEBEDEVA, Elena MAKAROVA, Alexander TATARKO. Increasing Intercultural Competence and Tolerance in Multicultural Schools: A Training Program and Its Effectiveness

Hence, we suggest that intercultural competences could be used as a predictor of intergroup anxiety.

\section{Training Effectiveness among Members of Ethnocultural Groups}

With regard to the effectiveness of the training program among the participants from ethnocultural groups of the Caucasus region, the findings indicated that the ambivalence of ethnic identity decreased significantly after the training $\left(\mathrm{M}_{\mathrm{pre}}=10.9 ; \mathrm{M}_{\text {post }}=8.5\right)$. The results also showed that the discomfort in intergroup interactions decreased significantly among the members of ethnocultural groups $\left(\mathrm{M}_{\mathrm{pre}}=5.4 ; \mathrm{M}_{\text {post }}=4.8\right)$. Moreover, optimism towards future interethnic relations increased significantly among ethnocultural group members, moving from an expression of uncertainty $\left(M_{\text {pre }}=15.8\right)$ to a positive rating $\left(M_{\text {post }}=19.0\right)$. Finally, the training participants from ethnocultural groups showed increasing levels of empathy towards majority group members $\left(\mathrm{M}_{\mathrm{pre}}=5.2 ; \mathrm{M}_{\mathrm{post}}=5.6\right)$ (see Table 7).

Table 7. Changes from pre- to post-survey (minority group sample).

\begin{tabular}{llllll}
\hline & $\begin{array}{l}\text { Pre } \\
(\mathbf{M})\end{array}$ & $\begin{array}{l}\text { Post } \\
(\mathbf{M})\end{array}$ & $\begin{array}{l}\text { Pre-Post } \\
\text { bias }\end{array}$ & $\begin{array}{l}\text { T-test } \\
\mathbf{p}\end{array}$ & $\begin{array}{l}\text { G-test } \\
\mathbf{p}\end{array}$ \\
\hline Ambivalence of ethnic identity & 10.9 & 8.5 & $(-)$ & 0.01 & 0.02 \\
Optimism towards interethnic relations & 15.8 & 19.0 & $(+)$ & 0.006 & n.s. \\
Discomfort in intergroup interactions & 5.4 & 4.8 & $(-)$ & 0.03 & n.s. \\
Empathy towards Russians & 5.2 & 5.6 & $(+)$ & 0.04 & n.s. \\
\hline Note: positive pre- and post-survey bias (+), negative pre- and post-survey bias (-); n.s.= non-significant.
\end{tabular}

As shown in Table 8, empathy towards Russians correlated negatively with discomfort in intergroup interactions among members of ethnocultural groups after the training.

Table 8. Correlation of the constructs in pre- and post-survey (minority group sample).

\begin{tabular}{lll}
\hline & Pre & \multicolumn{2}{c}{ Post } \\
& T & \multicolumn{1}{c}{$-0.22^{*}$} \\
\hline Empathy towards Russians/ Discomfort in intergroup interactions & n.s. & \\
\hline Note: ${ }^{*} \mathrm{p}<0.05,{ }^{* *} \mathrm{p}<0.01,{ }^{* * *} \mathrm{p}<0.001 ;$ n.s. $=$ non-significant. & &
\end{tabular}

Thus, we propose that empathy towards majority group members can decrease the discomfort in intergroup interactions for members of minority groups.

\section{Discussion}

The purpose of the study was to introduce the Training of Intercultural Competence and Tolerance (TICT) for school students in multicultural schools and discuss its effectiveness.

Overall, the evaluation of the TICT's effectiveness illustrated that the training leads, for participants from all ethnocultural groups participating in the training, to the development of a positive ethnic identity, the formation of a civic identity, and increased optimism in the assessment of future interethnic relations in Russia. These findings are in line with other research on the effectiveness of intercultural training programs. Despite the differences in the aims of particular intercultural trainings and the variety of training programs (context, content, methods, etc.), the TICT and other training programs have in common that they increase positive intercultural attitudes and awareness of differences among the participants (Behrnd, \& Porzelt, 2012; Fischer, 2011; Herfst, van Oudenhoven, \& Timmerman, 2008). 
Nadezhda M. LEBEDEVA, Elena MAKAROVA, Alexander TATARKO. Increasing Intercultural Competence and Tolerance in Multicultural Schools: A Training Program and Its Effectiveness

ROBLEMS

OF EDUCATION

IN THE $21^{\text {st }}$ CENTURY

Volume 54, 2013

More specifically, the evaluation of training effectiveness demonstrates that the participants of the Russian group reported reduced levels of anxiety towards future interactions with representatives of other ethnic groups (in particular with peoples of the Caucasus) and an increased subjective level of competence towards the cultures of the peoples of the Caucasus. Representatives of the cultures of the Caucasus, on the other hand, were able to strengthen their ethnic identity by defining it more clearly and making it more explicit; moreover, their optimism for good ethnic relations in Russia in the future increased, and their discomfort in interactions with representatives of other ethnic groups decreased. These effects of the training are especially valuable in light of empirical evidence based on studies of intercultural relations in multicultural societies which suggest a link between the feeling of being accepted by others, and accepting others. In the Russian Federation, members of a receiving society who feel secure have been shown to be more tolerant towards immigrants and more supportive of an ideology of multiculturalism (Lebedeva, \& Tatarko, 2009).

TICT did not have the same impact on trainees from different groups with respect to empathy towards outgroup members, a finding which concords with Fischer (2011, p. 773) who stated that the training effectiveness with respect to participants' intercultural awareness "differ [s] in decisive ways between groups". TICT participants from ethnocultural groups showed increasing levels of empathy towards the majority group, but there were no reciprocal changes among majority group members. One possible explanation for these group differences is the dominant group's strong tendency towards ethnocentrism; compared to other ethnocultural groups, it is "on top of the attitudinal hierarchy" (Barry et al., 2008, p. 372). The importance of cultural empathy for intercultural relations was shown in a study by Herfst et al. (2008, p. 74) who concluded that cultural empathy was one of the major predictors of intercultural effectiveness. Therefore, it is desirable, in future versions of the TICT program, to include further exercises to develop empathy among majority group members towards members of ethnocultural groups.

Furthermore, our results indicate that there were no significant changes after the TICT program in respondents' readiness to cooperate with members of opposite ethnocultural groups (i.e. for Russians to cooperate with representatives of peoples of the Caucasus, and for the representatives of the ethnocultural groups of the Caucasus to cooperate with Russians). This tendency to favor ingroup members underlines the prevalence of ethnocentrism in intercultural relations observed in interactions between other ethnocultural groups as well (Hagendoorn, 1993; Kalin, \& Berry, 1996). We therefore concur with Herfst et al.'s (2008, p. 75) conclusion from their Intercultural Effectiveness Training that "not all attitude changes and heightened awareness necessarily translate into actual behaviours" and suggest to include in future versions of TICT additional exercises which give students the possibility to build interethnic partnerships and, more generally, "provide students more opportunities for developing their skills in a safe environment" (Fischer, 2011, p. 774). Moreover, we propose to evaluate training effectiveness by means of an assessment of videotaped cross-cultural encounters both in role-plays and in real-life situations (Herfst et al., 2008, p. 75).

Our study has some limitations. Firstly, the TICT program lasted five days. In order to enhance training effects, follow-up training units should be implemented and their effect evaluated. Secondly, the training's effectiveness was assessed on the sixth day, which means that all reported positive effects of the TICT can, thus far, only be classified as short-term effects. Finally, our study primarily aimed to assess the effectiveness of the TICT program, which is why variables such as the trainees' or the trainers' characteristics were not included in the evaluation.

In summary, the evaluation of the TICT program has shown that the aims of the training have been achieved to a large extent. Furthermore, our evaluation of the TICT's effectiveness allows not only to highlight some aspects of the TICT program which should be improved, but it is also a valuable contribution to the research in the field because "a weak point of intercultural training programs is the lack of evaluation of their effects" (Berry et al., 2008, p. 418). 


\section{Conclusions}

The evaluation of the TICT's effectiveness has demonstrated its beneficial effects in various dimensions, such as strength of ethnic identity, development of a common civic identity, reduction of anxiety and discomfort during interactions with outgroup members, and fostering of Russian trainees' intercultural competences towards ethnocultural groups of the Caucasus. Thus, the Training of Intercultural Competence and Tolerance can be effectively used to prevent interethnic conflicts and to promote interethnic dialogue in multicultural schools.

With respect to the practical implementation of the TICT program, it is necessary to adapt the program to the cultural context of the particular training setting. "The fundamental reason why culture impacts training in general and cross-cultural training in particular is that educational practice is not only an individual intellectual activity but also a social process that takes place in certain cultural context" (Yang, Wang, \& Wang Drewry, 2009, p. 325).

With regard to future research on the training's effectiveness, the focus should be on long-term attitudinal and behavioral changes effected by cross-cultural training programs in general and the TICT in particular. Finally, research on the moderating effect of the trainees' or the trainers' characteristics should be the objective of a follow-up study on the training's effectiveness.

\section{Acknowledgements}

The study was partly supported by the Basic Research Program at the National Research University Higher School of Economics (HSE). The authors gratefully acknowledge this support.

\section{References}

Allport, G. W. (1954). The nature of prejudice. Cambridge: Addison-Wesley.

Bargal, D., \& Bar, H. (1992). A Lewinian approach to intergroup workshops for Arab-Palestinian and Jewish youth. Journal of Social Issues, 48, 139-154.

Behrnd, V., \& Porzelt, S. (2012). Intercultural competence and training outcomes of students with experiences abroad. International Journal of Intercultural Relations, 36, 213-223.

Berry, J. W. (2003). Conceptual approaches to acculturation. In K. M. Chun, P. Balls Organista, \& G. Marin (Eds.), Acculturation: Advances in theory, measurement, and applied research (pp. 17-38). Washington: American Psychological Association.

Berry, J. W. (2005). Acculturation: Living successfully in two cultures. International Journal of Intercultural Relations, 29, 697-712.

Berry, J. W. (2006a). Contexts of acculturation. In Sam, D. L. \& Berry, J. W. (Eds.), Cambridge Handbook of acculturation psychology (pp. 27-42). Cambridge: University Press.

Berry, J. W. (2006b). Stress perspectives on acculturation. In D. L. Sam, \& J. W. Berry (Eds.), Cambridge Handbook of acculturation psychology (pp. 43-57). Cambridge: University Press.

Berry, J. W., \& Kalin, R. (1995). Multicultural and ethnic attitudes in Canada: An overview of the 1991 national survey. Canadian Journal of Behavioural Science, 27 (3), 301-320.

Berry, J. W., \& Pleasants, M. (1984). Ethnic tolerance in plural societies. Paper given at the International Conference on Authoritarism and Dogmatism. Potsdam, NJ: Wiley.

Berry, J. W., Poortinga, Y. H., Breugelmans, S. M., Chasiotis, A., \& Sam, D. L. (2011). Cross-cultural Psychology. Research and Applications. Cambridge: University Press.

Berry, J. W., Poortinga, Y. H., Segall, M. H., \& Dasen, P. R. (2002). Cross-cultural psychology: research and applications. Cambridge: University Press.

Berry, J. W., \& Sabatier, C. (2010). Acculturation, discrimination, and adaptation among second generation immigrant youth in Montreal and Paris. International Journal of Intercultural Relations, 34, 191207.

Brown, R. (2000). Group processes. Dynamics within and between groups. Malden, MA: Blackwell Publishers. 
Nadezhda M. LEBEDEVA, Elena MAKAROVA, Alexander TATARKO. Increasing Intercultural Competence and Tolerance in Multicultural Schools: A Training Program and Its Effectiveness

PROBLEMS

OF EDUCATION

IN THE $21^{\text {st }}$ CENTURY

Volume 54, 2013

Bhawuk, D. P. S., \& Brislin, R. W. (2000). Cross-cultural training: A review. Applied Psychology: An International Review, 49, 162-191.

Brislin, R. W., \& Bhawuk, D. P. S. (1999). Cross-cultural training: Research and innovations. In J. Adamopoulos, \& Y. Kashima (Eds.), Social psychology and cultural context: Contributions of Harry Triandis to cross-cultural psychology (pp. 205-216). Thousand Oaks, CA: Sage.

Brislin, R. W., Cushner, K., Cherrie, C., \& Young, M. (1986). Intercultural interactions: A practical guide. Newbury Park, CA: Sage.

Brislin, R. W., \& Horvath, A. M. (1997). Cross-cultural Training and Multicultural Education. In J. W. Berry, M. H. Segall, \& Ç. Kagitçibasi (Eds.), Handbook of cross-cultural psychology: Vol. 3: Social behavior and application (pp. 327-369). Boston: Allyn \& Bacon.

Brislin, R., \& Yoshida, T. (1994). Intercultural communication training: An introduction. Thousand Oaks, CA: Sage.

Esses, V., Jackson, L., \& Armstrong, T. (1998). Intergroup competition and attitudes towards immigrants and immigration. Journal of Social Issues, 54, 699-724.

Fischer, R. (2011). Cross-cultural training effects on cultural essentialism beliefs and cultural intelligence. International Journal of Intercultural Relations, 35, 767- 775.

Gaertner, S. L., \& Dovidio, J. F. (2000). Reducing intergroup bias: The common ingroup identity model. Philadelphia, PA: Psychology Press.

Hagendoorn, L. (1993). Ethnic categorization and outgroup exclusion: The role of cultural values and social stereotypes in the construction of ethnic hierarchies. Ethnic and Racial Studies, 16, 26-51.

Herfst, S. L., van Oudenhoven, J. P., \& Timmerman, M. E. (2008). Intercultural Effectiveness Training in three Western immigrant countries: A cross-cultural evaluation of critical incidents. International Journal of Intercultural Relations, 32, 67-80

Hofstede, G. (1980). Culture's consequences: International differences in work-related values. Beverly Hills: Sage.

Islam, M. R., \& Hewstone, M. (1993). Dimensions of contact as predictors of intergroup anxiety, perceived outgroup variability and outgroup attitude: An integrative model. Personality and Social Psychology Bulletin, 19, 700-710.

Kalin, R., \& Berry, J. W. (1996). Interethnic attitudes in Canada: ethnocentrism, consensual hierarchy and reciprocity. Canadian Journal of Behavioural Science, 28, 253-261.

Landis, D., Bennett, J. M., \& Bennett, M. J. (Eds.) (2004). Handbook of intercultural training. Thousand Oaks, CA: Sage.

Lebedeva, N., \& Tatarko,A. (2003). Social'no-psihologicheskie faktory etnicheskoj tolerantnosti i strategii mezhgruppovogo vzaimodejstvija v polikul'turnyh regionah Rossii. [Socio-psychological factors of ethnic tolerance and the strategies of intergroup interaction in multicultural regions of Russia]. Psihologicheskij Zhurnal [Psychological Journal], 24 (5), 31-44.

Lebedeva, N. \& Tatarko, A. N. (Eds.) (2009). Strategii mezhkulturnogo vsaimodeistvia migrantov $i$ naselenia Rossii. Moscow: Peoples’ Friendship University of Russia.

Lebedeva, N., \& Tatarko, A. (2004). Socio-psychological factors of ethnic intolerance in Russia's multicultural regions. In B. Setiadi, A. Supratiknya, W. J. Lonner, \& Y. H. Poortinga (Eds.), Ongoing themes in psychology and culture. Selected papers from the sixteenth international congress of the International Association for Cross-Cultural Psychology. IACCP Press. Retrieved from: http://ebooks.iaccp.org/ongoing_themes/chapters/lebedeva/lebedeva.php?file=lebedeva\&o utput $=$ screen, on 2012-05-10.

Lebedeva N. M., Luneva, O. V., \& Stefanenko, T. G. (2004). Trening etnicheskoj tolerantnosti dlja shkol'nikov [The training of ethnic tolerance for schoolchildren]. Moscow: Privet.

Makarova, E., \& Herzog, W. (2011). The integration of immigrant youth into the school context. Problems of Education in the 21st Century, 32, 86-97.

Markus, H. R., \& Kitayama, S. (1991). Culture and the self. Implications for cognition, emotion, and motivation. Psychological Review, 98, 224-253.

Montreuil, A., \& Bourhis, R. Y. (2004). Acculturation orientations of competing host communities toward valued and devalued immigrants. International Journal of Intercultural Relations, 28, 507-532.

Navas, M., Garcia, M. C., Sanchez, J., Rojas, A. J., Pumares, P., \& Fernandez, J. S. (2005). Relative Acculturation Extended Model (RAEM). New contributions with regard to the study of acculturation. International Journal of Intercultural Relations, 29, 21-37. 
Pettigrew, T. F., \& Tropp, L. R. (2006). A meta-analytic test of intergroup contact theory. Journal of Personality and Social Psychology, 90 (5), 751-783.

Pfafferott, I., \& Brown, R. (2006). Acculturation preferences of majority and minority adolescents in Germany in the context of society and family. International Journal of Intercultural Relations, 30, 703-717.

Phinney, J. S. (2003). Ethnic identity and acculturation. In K. M. Chun, P. Balls Organista, \& G. Marin (Eds.), Acculturation: Advances in theory, measurement, and applied research (pp. 63-82). Washington: American Psychological Association.

Phinney, J. S., Horenczyk, G., Liebkind, K., \& Vedder, P. (2001). Ethnic identity, immigration, and wellbeing: An interactional perspective. Journal of Social Issues, 57 (3), 493-510.

Roccas, S., Horenczyk, G., \& Schwartz, S. H. (2000). Acculturation discrepancies and well-being: The moderating role of conformity. European Journal of Social Psychology, 30, 232-334.

Rot, J. \& Kopteltseva, G. (2001). Vstreci na grani kultur: Igry i uprazhneniia dlia mezhkulturnogo obuceniia (Meetings on the verge of cultures: Games and exercises for intercultural learning). Kaluga: Polygraph-inform (in Russian).

Sherif, M. (1966). Group conflict and cooperation: The social psychology. London: Routledge and Kegan.

Stephan, W. G., \& Stephan, C. W. (1996). Predicting prejudice. International Journal of Intercultural Relations, 20 (3/4), 409-426.

Stephan W. G., Stephan C. W. (2000). An integrated threat theory of prejudice. In S. Oscamp (Ed.), Reducing prejudice and discrimination (pp. 225-246). Mahwah, NJ: Lawrence Erlbaum.

Stephan W. G., \& Stephan C. W. (2001). Improving intergroup relations. Thousand Oaks, CA: Sage.

Tajfel, H., \& Turner, J. C. (1986). The social identity theory of intergroup behaviour. In S. Worchel, \& W. Austin (Eds.), Psychology of intergroup relations (pp. 7-24). Chicago: Nelson-Hall.

Taylor, D. (2002). The quest for identity. From minority groups to Generation Xers. Westport, CT: Praeger.

Federal State Statistics Service (2011). The Russian Census 2010. Retrieved from http://www.gks.ru/ free_doc/new_site/perepis2010/perepis_itogi1612.htm, on 2012-01-15.

Turner, J. C. (1985). Social categorization and self-concept: A social cognitive theory of group behavior. In E. J. Lawler (Ed.), Advances in group processes (Vol. 2, pp. 518-538). Greenwich, CT: JAI Press.

Voci, A., \& Hewstone, M. (2003). Intergroup contact and prejudice toward immigrants in Italy: The mediational role of anxiety and the moderational role of group salience. Group Processes and Intergroup Relations, 6, 37-54.

Ward, C. (2001). The ABCs of acculturation. In D. Matsumoto (Ed.), The handbook of culture and psychology (pp. 411-445). New York: Oxford University Press.

Ward, C., Bochner, S., \& Furnham, A. (2001). The psychology of culture shock. London: Routledge.

Yang, B., Wang, Y., \& Wang Drewry, A. (2009). Does it matter where to conduct training? Accounting for cultural factors. Human Resource Management Review, 19, 324-333.

Advised by Rita Makarskaité-Petkevičiene, Lithuanian University of Educational Sciences,

Lithuania

Received: April 08, 2013

Accepted: May 28, 2013 
Nadezhda M. LEBEDEVA, Elena MAKAROVA, Alexander TATARKO. Increasing Intercultural Competence and Tolerance in Multicultural Schools: A Training Program and Its Effectiveness

PROBLEMS

OF EDUCATION

IN THE $21^{\text {st }}$ CENTURY
Volume 54,2013
Nadezhda M. Lebedeva

PhD., Professor, Department of Psychology, National Research University - Higher School of Economics, 109316, 46-B, Volgogradsky prospekt,Moscow, Russia.

E-mail: nlebedeva@hse.ru

Website: http://www.hse.ru/org/persons/140031

\section{Elena Makarova}

PhD., University of Bern, Institute of Educational Science, Department of Educational Psychology , Muesmattstrasse 27, CH-3012 Bern, Switzerland.

Fax: +41 (0) 316318233 .

E-mail: elena.makarova@edu.unibe.ch

Website: http://edu.unibe.ch/content/app/mitarbeitende_app/dr_elena makarova/index_eng.html

Alexander Tatarko
PhD., Professor, Department of Psychology, National Research University - Higher School of Economics, 109316, 46-B, Volgogradsky prospect, Moscow, Russia.

E-mail: atatarko@hse.ru

Website: http://www.hse.ru/org/persons/66965 